\title{
Cyber Workplace Bullying: An Empirical Study
}

\author{
Yaser Y. Alahmad ${ }^{1}$, Hatem Bata ${ }^{2}$ \\ ${ }^{1}$ College of Business Administration, Albaha University, Albaha, KSA \\ ${ }^{2}$ Albany State University, Albany, USA \\ Email: *yalahmad@bu.edu.sa, hatem.bata@asurams.edu
}

How to cite this paper: Alahmad, Y. Y., \& Bata, H. (2021). Cyber Workplace Bullying: An Empirical Study. American Journal of Industrial and Business Management, 11, 767-784.

https://doi.org/10.4236/ajibm.2021.117048

Received: June 28, 2021

Accepted: July 19, 2021

Published: July 22, 2021

Copyright $\odot 2021$ by author(s) and Scientific Research Publishing Inc. This work is licensed under the Creative Commons Attribution International License (CC BY 4.0). http://creativecommons.org/licenses/by/4.0/

\begin{abstract}
Previous research on cyber workplace incivility (CWPI) is dependent and severely limited by psychological and social-psychological perspectives. This research builds on the previous studies by applying the Labor Process Theory with its core characteristics of power, control, and exploitation of labor so that further exploration of workplace incivility issues could be carried out. This research also uses Conservation of Resources (COR) Theory to explain the devastating long term negative impact of cyber workplace incivility on employees. The researchers also look at the role of technology due to increased connectivity, such as email, social media, mobile communication, blogs, and internet message boards at the workplace. This article contributes by looking at individual and institutional antecedents of CWPI and provides empirical support using a survey study.
\end{abstract}

\section{Keywords}

Workplace Incivility, Micromanagement, Autonomy, Autocratic Style, Democratic Style, Role Stress, Turnover, Job Satisfaction

\section{Introduction}

Workplace incivility is established as a significant research topic internationally. However, the different places still lag from the rest of the world in the identification and investigation of this phenomenon (Vega \& Comer, 2005). Many studies with a few exceptions examine workplace work-place incivility and its outcome within a psychological and social psychological framework. Some (Lewis \& Rayner, 2003; Hoel \& Beale, 2006; Beale \& Hoel, 2010; Hutchinson et al., 2010; Hutchinson \& Jackson, 2015) explore the concept of workplace.

Generally, workplace negative behaviors seen from the "eyes of labor process theory" are possibly "conceived as an endemic feature of the capitalist employment relationship" (Beale \& Hoel, 2011). According to (Beale \& Hoel, 2011), 
there are different ways in which labor process debates could explain, clarify, and develop the workplace work-place incivility literature. However, their arguments and observations lack the strong support of empirical evidence. According to (Namie, 2003), negative workplace behaviors happen on a continuum that starts with incivility, moves to bullying, and ends with workplace violence. This article explores the understanding of extreme behavioral action of work-place incivility using the literature based in a labor process conceptual framework. Workplace incivility is linked to financial loss, increased staff turnover, lowered morale, reduced productivity, and loyalty (Cooper et al., 1997; Quine, 1999). In fact, workplace work-place incivility could be a "more crippling and devastating problem for employees than all other work-related stress put together" (Einarsen, 1999). However, there are hardly any federal laws within United States, except for the proposed Healthy Workplace Bill (Yamada, 2004), which protects the victims' right to work in a safe and collegial office environment (Carbo, 2009; Maurer, 2013). Moreover, the currently proposed Healthy Workplace Bill also falls short of providing adequate remedial relief to the targets of workplace incivility (Carbo, 2009; Maurer, 2013). Most laws have focused on fighting discrimination, such as the equal employment opportunities, disability acts, and equal pay acts (Lueders, 2008). Nevertheless, there is no law that protects human dignity at work (Lueders, 2008). In contrast, the European systems are based on workers' dignity. Their laws protect personal and human rights against face-to-face workplace incivility, yet they have not reached the online arena (Lueders, 2008). At the same time, Ministry of Human Resources and Social Development at Saudi Arabia has a list of violation and penalties which protect the employee when any one of them try to assault physically, verbally or through electronic communication channels to any of colleague, manager (stakeholder) by terminating without Saudi service award based on Article 80 from the Saudi Labor Law.

Most of the current research on incivility critiques its face-to-face form, but with the increasing use of the technology and electronic communication, uncivil behaviors are becoming greater in online activities (Giumetti et al., 2012). Cyber incivility could be more harmful than face-to-face interactions, because the offender feels relatively safe behind the keyboard and experiences anonymity (Giumetti et al., 2012). Online messaging can be sent to multiple individuals, so the offender easily humiliates many people or a single target if he/she chooses. Most electronic communication is text-based; therefore pitch, tone, and body language are absent and open to misinterpretation (Giumetti et al., 2012). Furthermore, face-to-face workplace incivility is limited just to the work site during work hours. However, CWPI happens anytime of the day and regardless of the worker's location.

Therefore, unlike sexual harassment and other forms of workplace incivilities, CWPI is not prohibited, nor is the offender ostracized by the higher-level management (Baillien et al., 2009). The aggressor has the legitimate authority and responsibility to allocate work, assess work, and provide feedback to the victim. 
He or she misuses this authority without facing any disciplinary procedures by the management. All symptoms like anxiety, depression, and stress experienced by the victim are viewed by the senior management as personality characteristics-victim's inability to cope and lack of efficiency in his/her work performance (Baillien et al., 2009). If someone reported work-place incivility, she or he is typecast as a neurotic and hypersensitive person by the management. “... can be repackaged by management as being an illusion of the worker: it's all in the mind" (McIntyre, 2005), thus, making the victim of incivility face a significant backlash instead of the preparator.

\section{Theoretical Framework}

\subsection{The Labor Process Theory}

The entire concept of labor process theory is based on the ideology of paid employment, the relationship between employer and worker, which also includes management, unions, government, and state (McIntyre, 2005; Beale \& Hoel, 2011). Labor process theory argued that management used and controlled labor to generate profit. The major structure of the labor process theory is built on dominance.

In a factory system, workers no longer owned the instruments of production and were forced to sell their labor as their only means of livelihood. The capitalist, unlike the worker, was in possession of capital, enabling him or her to acquire the instruments of production and raw materials. The capitalist employed labor to transform raw materials into finished products that could be sold to earn a surplus and earn more profits (Braverman, 1974).

The capitalist main objective was to earn surplus or profits. To increase his or her profits, the capitalist utilized the labor power to its maximum potential. Under scientific management, labor power was reduced to a commodity. Scientific management resulted in a clear separation between execution and conception of labor process (Taylor, 2004). The functions of conception, coordination, and control were now performed by the management in a capitalist economy (Braverman, 1974).

This resulted in clear separation of the tasks of conception and execution, rendering workers and their labor a mere commodity. To quote (Milkman, 1997), "You [the employee] are a machine, an object, a piece of equipment. If it breaks, they will replace it. They don't care about the individual". It is true that scientific management increased production capacity and efficiency but simultaneously, and perhaps to a larger extent, it focused more on increasing management's control over labor, to remove any form of resistance and accumulate profits.

\subsection{Conservation of Resources (COR) Theory}

Conservation of Resources (COR) theory is built on the principle that individuals are driven to look after their existing resources i.e., conservation and 
obtain new resources i.e., acquisition. Resources are generally defined as objects, states, conditions, and other things that have value (Hobfoll, 1988). The value of resources is dependent on the individual personal experiences and situations.

According to COR, most individuals exhibit a primacy of resource loss meaning that it is psychologically more harmful for individuals to lose resources than it is helpful for them to gain the resources that they lost (Halbesleben et al., 2014). This means losses at work will have more impact than gains. Employees' lost resources at work are linked to negative psychological outcomes. This also have a motivational element as well because employees will engage in actions that avoid resource reduction since loss can have such an intense negative impact on their well-being (Halbesleben et al., 2014). The second principle is resource investment meaning that individuals are more likely to invest to protect against loss or to recover from losses (Halbesleben et al., 2014).

\subsection{Hypotheses Development}

A survey is used as a method to research the hypotheses in Figure 1. Structured Equations Modeling (SEM) using the Statistical package for the social science (SPSS) software is used to test the hypotheses significance and overall model fit. All the hypotheses were verified using the two-tailed and statistical significance for all analyses was set at .05. Furthermore, Pearson's $r$ was used to test the correlation between variables.

\section{Cyber Work-Place Incivility (CWPI)}

Generally, workplace incivility is defined as low-intensity deviant behavior at work with an ambiguous intent to harm (Schilpzand et al., 2016). Workplace incivility is distinct from other interpersonal workplace abusive behavioral constructs because it is less severe than aggression, violence, and bullying. It is also unclear, covert, or ambiguous intent to harm making it difficult to diagnose (Schilpzand et al., 2016). More covert abusive behavior is usually done by supervisors and bosses due to their more powerful positions, yet workplace incivility could be performed by anyone in the organization including peers, customers, and managers (Schilpzand et al., 2016).

Cyber workplace incivility (CWPI) is defined as communicative behavior that are exhibited in the context of using information technology interactions and that break workplace norms for mutual respect. The perpetrator of the cyber behavior may or may not mean to cause harm (Lim \& Chin, 2006). CWPI may include negative behaviors like using electronic communication to send messages in a discourteous tone, saying something hurtful, paying little attention for a request for communication, and using e-mail for time-sensitive messages such as canceling or scheduling a meeting on short notice (Park et al., 2018).

1) Antecedents of workplace work-place incivility

a) Management Control 
$\begin{array}{ll}\text { A) Management } & \text { C) Consequences }\end{array}$

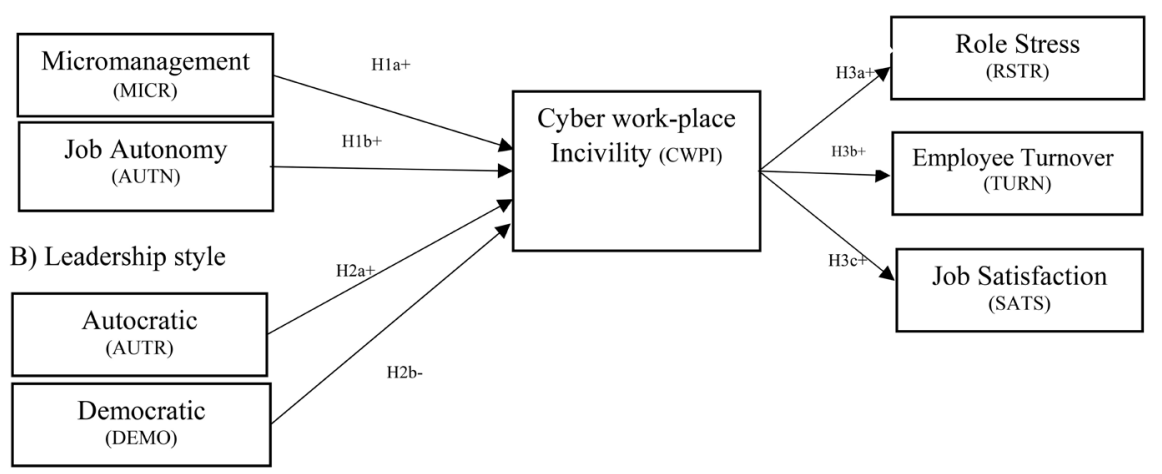

Figure 1. Antecedents and consequences of cyber workplace incivility hypotheses model.

Management controls are the actions of employees within an organization who are encouraged to perform certain actions while discouraged from doing other actions to achieve organizational goals (Theodosiou \& Katsikea, 2007). Management control falls into two broad categories of micromanagement and job autonomy.

Micromanagement is defined as a management control where a manager closely observes or controls the work of an employee. It shows lack of trust between the manager and the employees and lack of the manager's self confidence in his/her in education, knowledge, skills, or abilities (Frensh \& Mulyadi, 2019). Generally, it is more likely that people at higher level of the organization target people at lower level of the organization with uncivil electronic communication. These managers and supervisors who have control of organizational resources probably hold more power over their subordinates and are less likely to be held accountable for their negative actions (Pearson et al., 2000).

According to (Knight, 2015), Micromanagement style managers like to be carbon copied in all employee's electronic communication, seldom satisfied with their employee's work, and want to control the smallest details. These managers may not trust themselves or their employees and are more likely to use uncivil language in their electronic communication to compensate for their lack of self-confidence. (Porath \& Pearson, 2012) found that being targeted by incivility is strongly related with being with angry and fearful. Anger and fear are indicators of managers who have low self-confidence and are more likely to engage in micromanagement potentially leading to uncivil CWPI.

Based on Labor process theory, a manager views his or her employees as replaceable cogs in a machine that aims to generate profits (Milkman, 1997). These micromanagers, obsessed with controlling their employees, are less likely to pay attention to the feelings of their workers and more likely to engage in uncivil behavior. Poverty may induce workers to accept uncivil behavior which could make managers see that uncivil behavior does not have consequences thus engaging in more offences (Denenberg \& Braverman, 2001).

$H 1$ a: The higher the micromanagement controls the higher the cyber workplace work-place incivility. 
Managers who practice job autonomy (AUTN) with their employees by enabling them through freedom, independence, and discretion to schedule their own work, make and select the methods used to perform their tasks (Hackman \& Oldham, 1975). AUTN allows employees to define their role because they will have greater discretion in deciding how to perform the work (Hackman \& Oldham, 1975).

Managers who give their employees autonomy are more likely to engage in cyber workplace uncivility, when employees have more control over their work, there is a higher probability of power struggles between employees and their managers resulting in more resentment and negative communication (Spector, 1986). Autonomy may not encourage cooperation since managers and employees are more likely to work alone, potentially giving employees and managers the impression that cordiality is not an important leading to more conflict (Seigel, 2004). This negative communication is more likely to take place electronically leading to higher CWPI.

$H 1 b$ : The higher the responsible autonomy the higher the cyber workplace work-place incivility.

b) Managerial leadership style factors

Managerial leadership styles are the methods of providing guidance and direction, implementing plans, and motivating employees (Kotter, 2001). These include the total pattern of explicit and implicit actions taken by the leader. The autocratic and the democratic leadership styles are the main leadership styles that may impact CWPI. For example, an autocratic leadership style is where a manager makes decisions without employees' participation or with little input from employees. These leaders make choices based on their own ideas and judgments and rarely accept advice, thus exercising absolute, authoritarian control over their subordinates (Ardichvili \& Kuchinke, 2002).

Labor process theory postulates that autocratic managers focus on subordination of workers by using control techniques that emphasize coercion and less civility (Akella, 2016). These managers are more likely to humiliate and dehumanize their employees to increase obedience and reduce dissent or resistance among lower ranks (Akella, 2016). Autocratic managers are more likely to be coercive, distant, and production-oriented management, hence may be less interested in fostering positive relationships with their employees (Sakurai, 2020). These managers are more likely to engage in uncivility online because they care only about compliance and dominating their subordinates through technology as a means of public ridiculing, usurping credit for employee's successes, and scapegoating employees (Schyns \& Schilling, 2013).

H2a: The higher the autocratic style the higher the cyber workplace work-place incivility.

A democratic leader makes decision through consulting his/her employees and soliciting their input or opinion, thus making employees' input valuable by encouraging positive communication, build positive relationships between employees (Sharma \& Singh, 2013). Democratic managers depend upon group de- 
cision making, active member involvement. honest praise and criticism, and a degree of comradeship (Gastil, 1994). Democratic managers operate ordering to (Giltinane, 2013) subordinates feel valued when a democratic leader shares his/her vision to achieve work goals and encourages members to be creative, problem solve and grow professionally This type of manager is likely to encourage positive electronic communication and is unlikely to engage in cyber work-place incivility.

$H 2 b$ : The higher the democratic style the lower the cyber workplace incivility.

\section{2) Consequences of CWPI}

Role stress is sometimes seen as the result of the difference between an employee's perception of their role and what is being done by that employee within a company. Hence, role stress occurs when there is discrepancy between expectations and reality resulting in emotional exhaustion (Lambert \& Lambert, 2001). Being a victim of incivility may lead to increase stress due to the increase in the stress in the work environment. The recipient of the incivility may experience psychological stress due to the unpleasant exchange and increased probability of interpersonal conflict (Penney \& Spector, 2005). An employee receiving a rude electronic communication from his/her boss and may feel compelled to respond but is unable because he/she has a lower position resulting and thus absorbs the stress projected from the superior.

According to COR, employees try to gain, protect, and build resources. Stressors in the environment such as cyber incivility consume resources because cyber incivility drain cognitive and emotional resources through rude and discourteous actions. These stressors in turn may perhaps increase the employee's role stress. Employees who experience incivility are more likely to cognitively perceive it as threatening making incivility targets report psychological distress after the incivility encounter (Thompson et al., 2016). Acts of cyber incivility are difficult to forget, leading targets to remember the mistreatment, because they are a permanent record of these incidents online, thus making them more stressful.

H3a: The higher the cyber workplace work-place incivility the higher the role stress.

Employee turnover (TURN) is the withdrawal decision process in a series of several psychological steps: that includes evaluation of job, thinking of quitting, evaluation of expected utility of search and cost of quitting, intention to search for alternatives, search for alternatives, evaluation of alternatives, comparison of alternatives versus present job and deciding to leave the job or stay (Mobley, 1977). If there are positive relations and interactions between employees and their managers, they are less likely to voluntarily leave their jobs (Rahim \& Cosby, 2016). However, cyber incivility may lead to increased hostility in the workplace and increasing hostility leading employees to consider transferring to another department or resigning.

According to COR theory, if an employee's experiences the stress of loss of resources or psychological loss of dignity from cyber incivility potentially acting 
as micro-stressors, these micro-stressors are going to accumulate over time making employees less loyal to the organization. In time, they may be more likely to leave their job (Giumetti et al., 2013). Employees are also more likely to withdraw from work physically or physiologically to restore these resources (Wright \& Cropanzano, 1998).

$H 3 \mathrm{~b}$ : The higher the workplace work-place incivility the higher the employee turnover.

Job satisfaction (SATS) is how employees feel or their emotional response about different dimensions of their job. It is the extent that employees like or dislike their job (Spector, 1997). Employees who are exposed to cyber incivility may become dissatisfied with their jobs because they may develop negative affect towards their job (Giumetti et al., 2016). This negative attitude coming from the hostile work environment may create a negative sense of personal wellbeing making the employee unhappy and spending time focusing on work problems, even outside work hours leading to growing resentment of their workplace (Lim et al., 2008). Based on COR theory, that incivility can deplete individuals' resources and lead to decreased job dissatisfaction.

H3c. The higher the workplace work-place incivility the lower the job satisfaction.

\section{Research Design and Methodology}

\subsection{Data Analysis}

The SPSS version 21 (IBM SPSS Statistics) was used to conduct the data analysis. All statistical tests were two-tailed and statistical significance for all analyses was set at .05. We first performed the normality test and homogeneity test of variance. Then, descriptive statistics were used to describe the participants' socio-demographic characteristics and the variables scores. Pearson's r correlations were used to examine the associations between the variables (MICR, AUTN, AUTR, DEMO, CWPI, RSTR, TURN, and SATS) scores. The structural equation modeling (SEM) with maximum likelihood and bootstrapping methods were used to test the hypothesized model (Figure 1).

\subsection{Data Collection}

A survey was created based on items that were used in previous research in the field. Total of 2500 surveys were distributed, and the response rate was approximately $5.9 \%$. The data analysis is based on the 148 usable questionnaires. Since, the researchers set the confidence level at $95 \%$. This required a sample a minimum sample size of 87 to be able to conduct the research (Krejcie \& Morgan, 1970). Since there are 148 respondents, this is more than enough.

The low response rate may have occurred because many individuals lost their jobs or changed their jobs because of the Covid-19 pandemic and therefore were out of the researchers' reach due to changing their contact information. Furthermore, the Covid-19 pandemic was considered a unique opportunity for researchers to examine interesting social, economic, and business topics, thus 
many of them send surveys to participants in several organizations. Consequently, these individuals received many surveys and may have stopped answering surveys due to research fatigue. This happens when potential participants of interest become tired of engaging with research, consequently avoiding further participation (Patel et al., 2020).

\subsection{The Sample List}

The sample for the study was randomly selected from the people that are working for a Saudi organization. Most respondents (62.8\%) are working for a private sector, and $32.4 \%$ of respondents were working for a public organization. In terms of education level, over $40 \%$ of the sample had earned a bachelor's degree. Almost 28.4\% of the sample had earned master's degree; and 22.3\% of them had earned $\mathrm{PhD}$. Male respondents comprised $93.2 \%$ of the sample. The details of the demographic data are shown in Table 2.

\subsection{Data Analysis}

The SPSS version 21 (IBM SPSS Statistics, Armonk, NY, USA) was used to conduct the data analysis. All statistical tests were two-tailed and statistical significance for all analyses was set at .05 . We first performed the normality test and homogeneity test of variance. Then, descriptive statistics were used to describe the participants' sociodemographic characteristics and the variables scores Table 1. Pearson's correlations were used to examine the associations between the variables Table 3. The structural equation modelling (SEM) with maximum likelihood and bootstrapping methods were used to test the hypothesized model (Figure 1).

\subsection{Measurement Scales}

Survey questions and descriptive statistics for each survey statement are presented in Table 1. Each statement required responses based on a 5-point Likert scale $(1=$ Strongly disagree to $5=$ Strongly agree). Questions MICR1 to MICR6 were used to measure Micromanagement, the (6 items) of micromanagement were adapted from (Jaworski \& MacInnis, 1989); questions AUTN1 to AUTN4 were used to measure Job autonomy, the ( 4 items) of job autonomy were adapted from (Thompson \& Prottas, 2006); questions AUTR1 to AUTR3 were used to measure the autocratic style, the ( 3 items) of autocratic style were adapted from (Warrick, 1981); questions DEMO1 to DEMO5 were used to measure the democratic style, the (5 items) of democratic style were adapted from (Warrick, 1981); questions CWPI1 to CWPI7 were used to measure the cyber workplace incivility, the (7 items) of CWPI were adapted from (Cortina et al., 2001); questions RSTR1 to RSTR5 were used to measure the role stress, the (5 items) of role stress were adapted from (Rizzo et al., 1970); questions TURN1 to TURN3 were used to measure the employee turnover, the ( 3 items) of employee turnover were adapted from (Seashore et al., 1982); job satisfaction were measured by questions 
SATS1 to SATS3, the (3 items) of job satisfaction were adapted from (Hackman \& Oldham, 1974).

Table 1. Survey questions and descriptive statistics.

\begin{tabular}{|c|c|c|c|}
\hline $\begin{array}{l}\text { Item } \\
\text { code }\end{array}$ & Survey question & Mean & $\begin{array}{l}\text { Std. } \\
\text { Deviation }\end{array}$ \\
\hline MICR1 & My immediate boss monitors the extent to which I attain my performance goals. & 3.53 & 1.065 \\
\hline MICR2 & I receive feedback from my immediate supervisor concerning the extent to which I achieve my goals. & 3.36 & .997 \\
\hline MICR3 & My immediate boss monitors the extent to which I follow established procedures. & 3.27 & 1.116 \\
\hline MICR4 & My immediate boss evaluates the procedures I use to accomplish a given task. & 3.30 & 1.086 \\
\hline MICR5 & My immediate boss modifies my procedures when desired results are not obtained & 3.30 & 1.067 \\
\hline MICR6 & I receive feedback on how I accomplish my performance goals. & 3.32 & 1.076 \\
\hline AUTN1 & I have the freedom to decide what I do on my job & 3.12 & 1.130 \\
\hline AUTN 2 & I have a lot of say about what happens on my job & 3.27 & 1.085 \\
\hline AUTN 3 & I decide when I take breaks & 3.22 & 1.148 \\
\hline AUTN 4 & It is basically my own responsibility to decide how my job gets done. & 3.26 & 1.039 \\
\hline AUTR1 & Employees need to be supervised closely, or they are not likely to do their work & 2.80 & 1.256 \\
\hline AUTR 2 & It is fair to say that most employees in the general population are lazy. & 2.43 & 1.064 \\
\hline AUTR 3 & $\begin{array}{l}\text { As a rule, employees must be given rewards or punishments to motivate them to achieve organizational } \\
\text { objectives }\end{array}$ & 2.76 & 1.406 \\
\hline DEMO1 & Employees want to be a part of the decision-making process. & 3.46 & 1.109 \\
\hline DEMO 2 & Providing guidance without pressure is the key to being a good leader. & 3.44 & 1.120 \\
\hline DEMO 3 & Most workers want frequent and supportive communication from their leaders. & 3.51 & 1.134 \\
\hline DEMO 4 & Leaders need to help subordinates accept responsibility for completing their work. & 3.48 & 1.152 \\
\hline DEMO 5 & People are basically competent and if given a task will do a good job. & 3.32 & 1.051 \\
\hline CWPI1 & Put you down or was condescending to you in some way. & 3.07 & 1.119 \\
\hline CWPI2 & Paid little attention to a statement you made or showed little interest in their opinion & 3.27 & 1.001 \\
\hline CWPI3 & Made demeaning, rude, or derogatory remarks about you & 3.08 & 1.104 \\
\hline CWPI4 & Addressed you in unprofessional terms, either privately or publicly & 3.05 & 1.148 \\
\hline CWPI5 & Ignored or excluded you from professional camaraderie (e.g. social conversation) & 3.16 & 1.092 \\
\hline CWPI6 & Doubted your judgment in a matter over which you have & 3.18 & 1.054 \\
\hline CWPI7 & Made unwanted attempts to draw you into a discussion of personal matters. & 2.98 & 1.116 \\
\hline RSTR1 & I know exactly what is expected of me. (R) & 2.12 & .872 \\
\hline RSTR 2 & I know what my responsibilities are. $(\mathrm{R})$ & 1.98 & .907 \\
\hline RSTR 3 & Explanation is clear of what must be done. (R) & 2.34 & .915 \\
\hline RSTR 4 & I have clear, planned goals and objectives for my job. (R) & 2.35 & 1.042 \\
\hline RSTR 5 & I feel certain about how much authority I have. (R) & 2.38 & 1.020 \\
\hline TURN1 & I will actively look for a new job & 3.30 & 1.135 \\
\hline TURN2 & I often think about quitting & 3.04 & 1.148 \\
\hline TURN3 & I will probably look for a new job by the next month & 3.26 & 1.095 \\
\hline SATS1 & Overall, I feel satisfied with my job & 2.14 & .969 \\
\hline SATS2 & I feel happy with my job for the most part & 2.19 & .891 \\
\hline SATS3 & I think that my job generally pleases me. & 2.22 & .917 \\
\hline
\end{tabular}




\subsubsection{Validity and Reliability of the Instrument}

The validation process for the survey instrument included two steps: content validity and reliability. The literature review and in-depth interviews conducted with different respondents and researchers established the basis of content validity, showing that the items measured what they were purported to measure. Reliability was measured by Cronbach's alpha. The lower limit of .7 is considered acceptable for established scales (Nunnally \& Bernstein, 1994). All constructs have Cronbach's Alpha values above .810 , which indicates adequate internal consistency. Cronbach's coefficient alpha is shown in Table 3.

\subsubsection{The Results of Measurement Scale}

The results of the measurement scales are shown in Table 4; All scales have Cronbach's alpha value of .8 or higher. Table 2 also reports the mean value and standard deviation of each item in the survey.

\subsubsection{Correlation Analysis}

The next step was to conduct a correlation analysis between variables. Table 3 presents the bivariate correlation between all variables (MICR, AUTN, AUTR, DEMO, CWPI, RSTR, TURN, and SATS). As Table 3 shows, each construct shares a greater variance with its own measures than with any other construct. This reveals that each construct is more closely related to its own measures than to those of other constructs, thereby confirming the discriminant validity (Fornell \& Bookstein, 1982).

Table 2. Respondent characteristics.

\begin{tabular}{|c|c|c|c|}
\hline Classification & Sub-Classification & Frequency & Percentage \\
\hline \multirow{2}{*}{ Gender } & Male & 138 & 93.2 \\
\hline & Female & 10 & 6.8 \\
\hline \multirow{5}{*}{ Age } & 20 - 30 years & 11 & 7.4 \\
\hline & 31 - 40 years & 61 & 41.2 \\
\hline & $41-50$ years & 60 & 40.5 \\
\hline & $51-60$ years & 15 & 10.1 \\
\hline & More than 60 years & 1 & .7 \\
\hline \multirow{4}{*}{ Education } & High school & 13 & 8.8 \\
\hline & Bachelor's & 60 & 40.5 \\
\hline & Master's & 42 & 28.4 \\
\hline & $\mathrm{PhD}$. & 33 & 22.3 \\
\hline \multirow{5}{*}{ Employee status } & Work for private company & 93 & 62.8 \\
\hline & Work for public organization & 48 & 32.4 \\
\hline & Self-employment & 5 & 3.4 \\
\hline & Retired & 1 & .7 \\
\hline & Unemployment & 1 & .7 \\
\hline
\end{tabular}


Table 3. Correlation and reliability.

\begin{tabular}{|c|c|c|c|c|c|c|c|c|c|c|}
\hline Construct & Reliability & No. of Items & MICR & AUTN & AUTR & DEMO & CWPI & RSTR & TURN & SATS \\
\hline MICR & .893 & 6 & 1 & & & & & & & \\
\hline AUTN & .889 & 4 & $.423^{* *}$ & 1 & & & & & & \\
\hline AUTR & .866 & 3 & .137 & .087 & 1 & & & & & \\
\hline DEMO & .940 & 5 & -.104 & $-.240^{* *}$ & -.082 & 1 & & & & \\
\hline CWPI & .956 & 7 & $.411^{* *}$ & $.599^{* *}$ & .123 & $-.335^{* *}$ & 1 & & & \\
\hline RSTR & .840 & 5 & $-.163^{*}$ & $-.231^{* *}$ & -.138 & -.079 & .005 & 1 & & \\
\hline TURN & .810 & 3 & -.062 & .051 & $.189^{*}$ & -.122 & $.212^{* *}$ & .044 & 1 & \\
\hline SATS & .881 & 3 & .057 & -.071 & .051 & -.115 & -.069 & -.084 & .039 & 1 \\
\hline
\end{tabular}

** Correlation is significant at the .01 level (2-tailed).

Table 4. Model fit.

\begin{tabular}{|c|c|c|c|c|c|c|c|c|c|}
\hline \multicolumn{10}{|c|}{ Model Summary } \\
\hline \multirow{2}{*}{ Model } & \multirow{2}{*}{$\mathrm{R}$} & \multirow{2}{*}{ R Square } & \multirow{2}{*}{$\begin{array}{l}\text { Adjusted R } \\
\text { Square }\end{array}$} & \multirow{2}{*}{$\begin{array}{l}\text { Std. Error of the } \\
\text { Estimate }\end{array}$} & \multicolumn{5}{|c|}{ Change Statistics } \\
\hline & & & & & R Square Change & F Change & df1 & df 2 & Sig. F Change \\
\hline 1 & $.655^{\mathrm{a}}$ & .429 & .413 & 5.20553 & .429 & 26.843 & 4 & 143 & .000 \\
\hline
\end{tabular}

a. Predictors: (Constant), DEMO, AUTR, MICR, AUNT; dependent variable: CWPI.

\section{Results and Discussion}

Table 1 shows that the mean score and standard deviation of all variables. It shows that the score of MICR, AUTN, DEMO, and TURN is much higher than other variables like AUTR, RSTR and SATS indicating significant use of those variables. At the same time, indicating a lack of use of the lowest score which included AUTR, RSTR, and SATS. We used multiple regression to test the relationship and the statistical significance of the parameters using a t-test in the structural model (Chin, 1998). The variance explained $\left(R^{2}\right)$ and the significance of the path coefficient indicates the quality of the model (Chin, 1998). Table 4 shows the result of the model. The $R^{2}$ value was .429 , indicating that the model explains a good amount of the variance in CWPI.

We hypothesized that the higher the micromanagement control the higher the CWPI. The results show that H1a is strongly supported and statistically significant as shown by $\left(\beta .187={ }^{* * *}\right.$; $t$-value $\left.=2.658\right)$. This result provides empirical evidence for the strong impact of micromanagement on workplace work-place incivility. We also hypothesized that the higher the responsible autonomy the higher the CWPI. H1b is strongly supported and statistically significant as shown by $\left(\beta .468={ }^{* *}\right.$; $t$-value $\left.=6.556\right)$. This result provides empirical evidence for the strong impact of autonomy on workplace work-place incivility. These statistical results highlight the importance of control methods on CWPI.

Nevertheless, managerial leadership styles have shown mixed results. H2a, which links autocratic leadership style to CWPI, was not found to be statistically 
significant. This inconclusive outcome may be because the research was conducted during the Covid-19 pandemic. During a crisis employee are more likely to need clear guidance for what needs to be done, when it should be done, and how it should be done (Khan et al., 2015). Hence, employees may tend to be more open of autocratic leadership. Nevertheless, the findings related to $\mathrm{H} 2 \mathrm{~b}-$ the higher the democratic style the lower the CWPI-indicate a negative relationship with CWPI. H2b is strongly supported and statistically significant as shown by the results of $\beta .200{ }^{* *} ; t$-value $=3.060$. Furthermore, this study shows that democratic management style involves reaching decisions with the input of the employees is likely to encourage positive electronic communication and is unlikely to engage in CWPI. Therefore, different styles may be required for different situations and a smart leader may need to know when to exhibit a particular approach.

Furthermore, there was mixed evidence about the implications of CWPI. H3a, the higher the CWPI the higher the role stress, was not shown to be statistically significant Also, the findings show that $\mathrm{H} 3 \mathrm{c}$, the higher the workplace work-place incivility the lower the job satisfaction, is not supported and statistically is not significant. However, as we hypothesized that the higher the workplace work-place incivility the higher the employee turnover. The results show that $\mathrm{H} 3 \mathrm{~b}$ is strongly supported and statistically significant as shown by $\beta .212{ }^{* *}$; $\mathrm{t}$-value $=2.616$. The results are summarized in Table 5. It is also possible that the impact of cyber workplace incivility may not have an immediate short-term impact of employees' job satisfaction or role stress, but it builds gradually overtime leading to higher turnover.

\section{Implications, Limitations, and Future Research}

\subsection{Implications for Practitioners}

Managers should try to create a positive work environment with high employee autonomy, more democratic style to reduce cyber workplace incivility, so there

Table 5. Summary of Hypothesis results.

\begin{tabular}{cccccc}
\hline \multirow{2}{*}{ Hypothesis } & Relationship & Path & & \multicolumn{2}{c}{ Resulting support } \\
& & Coefficient & t-value & Significant & Hypothesis supported? \\
\hline H1a & Micromanagement $\rightarrow$ cyber workplace incivility & .187 & 2.658 & & Y** \\
H1b & Autonomy $\rightarrow$ cyber workplace incivility & .468 & 6.556 & $* * *$ & Yes \\
H2a & Autocratic $\rightarrow$ cyber workplace incivility & .040 & .624 & No & No \\
H2b & Democratic $\rightarrow$ cyber workplace incivility & -.200 & -3.060 & $* *$ & Yes \\
H3a & cyber workplace incivility $\rightarrow$ role stress & .005 & .056 & No & No \\
H3b & cyber workplace incivility $\rightarrow$ job turnover & .212 & 2.616 & $* *$ & Yes \\
H3c & cyber workplace incivility $\rightarrow$ job satisfaction & -.069 & -.835 & No & No
\end{tabular}

Note: ${ }^{*} p$-value $<.01,{ }^{* *} p$-value $<.05,{ }^{* * *} p$-value $<.001$, respectively. 
is less turnover in employees. Managers should know problems with job satisfaction and role stress may be a result of cyber workplace incivility but may take time to build up to a critical level leading to higher turnover.

As shown in this paper, employees are more likely to quit their jobs because of high cyber workplace incivility. High turnover could lead to incurring training, on-boarding, administrative, recruitment costs (Ramlawati et al., 2021). Managers may also be required to be more autocratic during a crisis to give clear directions and guidance to their employees.

\subsection{Limitations and Future Research}

The survey was conducted during the Covid- 19 pandemic during a time where many people lost their jobs and those who remained in the workforce faced great insecurities, thus may not be concerned about cyber workplace incivility. Future research could be conducted at a time where the economy is either stable or booming and employees have more job opportunities to compare how they will they be affected by uncivil behavior. This research focused on supervisors' and managers' cyber workplace incivility. Future research may explore customer CWPI to receive a more holistic view of incivility within an organization.

\section{Conflicts of Interest}

The authors declare no conflicts of interest regarding the publication of this paper.

\section{References}

Akella, D. (2016). Workplace Bullying: Not a Manager's Right? SAGE Open, 6. https://doi.org/10.1177/2158244016629394

Ardichvili, A., \& Kuchinke, K. P. (2002). Leadership Styles and Cultural Values among Managers and Subordinates: A Comparative Study of Four Countries of the Former Soviet Union, Germany, and the US. Human Resource Development International, 5, 99-117. https://doi.org/10.1080/13678860110046225

Baillien, E. et al. (2009). A Qualitative Study on the Development of Workplace Bullying: Towards a Three Way Model. Journal of Community \& Applied Social Psychology, 19, 1-16. https://doi.org/10.1002/casp.977

Beale, D., \& Hoel, H. (2010). Workplace Bullying, Industrial Relations and the Challenge for Management in Britain and Sweden. European Journal of Industrial Relations, 16, 101-118. https://doi.org/10.1177/0959680110364826

Beale, D., \& Hoel, H. (2011). Workplace Bullying and the Employment Relationship: Exploring Questions of Prevention, Control and Context. Work, Employment and Society, 25, 5-18. https://doi.org/10.1177/0950017010389228

Braverman, H. (1974). Labor and Monopoly Capital. Monthly Review Press. https://doi.org/10.14452/MR-026-03-1974-07 1

Carbo, J. (2009). Strengthening the Healthy Workplace Act-Lessons from Title VII and IIED Litigation and Stories of Targets' Experiences. Journal of Workplace Rights, 14, 97-120. https://doi.org/10.2190/WR.14.1.f

Chin, W. W. (1998). The Partial Least Squares Approach to Structural Equation Model- 
ing. Modern Methods for Business Research, 295, 295-336.

Cooper, M. C. et al. (1997). Meshing Multiple Alliances. Journal of Business Logistics, 18, 67.

Cortina, L. M. et al. (2001). Incivility in the Workplace: Incidence and Impact. Journal of Occupational Health Psychology, 6, 64. https://doi.org/10.1037/1076-8998.6.1.64

Denenberg, R. V., \& Braverman, M. (2001). The Violence-Prone Workplace: A New Approach to Dealing with Hostile, Threatening, and Uncivil Behavior. Cornell University Press.

Einarsen, S. (1999). The Nature and Causes of Bullying at Work. International Journal of Manpower, 20, 16-27. https://doi.org/10.1108/01437729910268588

Fornell, C., \& Bookstein, F. L. (1982). Two Structural Equation Models: LISREL and PLS Applied to Consumer Exit-Voice Theory. Journal of Marketing Research, 19, 440-452. https://doi.org/10.1177/002224378201900406

Frensh, W., \& Mulyadi, M. (2019). Criminal Policy in Preventing Cyberharassment as a Negative Impact of Technology. The 1st Workshop on Multimedia Education, Learning, Assessment and Its Implementation in Game and Gamification in Conjunction with COMDEV 2018, Medan, 26 January 2019. https://doi.org/10.4108/eai.26-1-2019.2283260

Gastil, J. (1994). A Definition and Illustration of Democratic Leadership. Human Relations, 47, 953-975. https://doi.org/10.1177/001872679404700805

Giltinane, C. L. (2013). Leadership Styles and Theories. Nursing Standard, 27, 35-39. https://doi.org/10.7748/ns2013.06.27.41.35.e7565

Giumetti, G. W. et al. (2012). Cyber Incivility@ Work: The New Age of Interpersonal Deviance. Cyberpsychology, Behavior, and Social Networking, 15, 148-154.

https://doi.org/10.1089/cyber.2011.0336

Giumetti, G. W. et al. (2013). What a Rude e-Mail! Examining the Differential Effects of Incivility versus Support on Mood, Energy, Engagement, and Performance in an Online Context. Journal of Occupational Health Psychology, 18, 297.

https://doi.org/10.1037/a0032851

Giumetti, G. W. et al. (2016). Linking Cyber Incivility with Job Performance through Job Satisfaction: The Buffering Role of Positive Affect. Psi Chi Journal of Psychological Research, 21, 230-240. https://doi.org/10.24839/2164-8204.JN21.4.230

Hackman, J. R., \& Oldham, G. R. (1974). The Job Diagnostic Survey: An Instrument for the Diagnosis of Jobs and the Evaluation of Job Redesign Projects.

Hackman, J. R., \& Oldham, G. R. (1975). Development of the Job Diagnostic Survey. Journal of Applied Psychology, 60, 159. https://doi.org/10.1037/h0076546

Halbesleben, J. R. et al. (2014). Getting to the COR Understanding the Role of Resources in Conservation of Resources Theory. Journal of Management, 40, 1334-1364.

https://doi.org/10.1177/0149206314527130

Hobfoll, S. E. (1988). The Ecology of Stress. Taylor \& Francis.

Hoel, H., \& Beale, D. (2006). Workplace Bullying, Psychological Perspectives and Industrial Relations: Towards a Contextualized and Interdisciplinary Approach. British Journal of Industrial Relations, 44, 239-262. https://doi.org/10.1111/j.1467-8543.2006.00496.x

Hutchinson, M., \& Jackson, D. (2015). The Construction and Legitimation of Workplace Bullying in the Public Sector: Insight into Power Dynamics and Organisational Failures in Health and Social Care. Nursing Inquiry, 22, 13-26.

https://doi.org/10.1111/nin.12077 
Hutchinson, M. et al. (2010). Bullying as Circuits of Power: An Australian Nursing Perspective. Administrative Theory \& Praxis, 32, 25-47. https://doi.org/10.2753/ATP1084-1806320102

Jaworski, B. J., \& MacInnis, D. J. (1989). Marketing Jobs and Management Controls: Toward a Framework. Journal of Marketing Research, 26, 406-419. https://doi.org/10.1177/002224378902600403

Khan, M. S. et al. (2015). The Styles of Leadership: A Critical Review. Public Policy and Administration Research, 5, 87-92.

Knight, R. (2015). How to Stop Micromanaging Your Team. Harvard Business Review.

Kotter, J. P. (2001). What Leaders Really Do. Harvard Business School Publishing Corporation. https://doi.org/10.1108/bl.2000.17013aae.001

Krejcie, R. V., \& Morgan, D. W. (1970). Determining Sample Size for Research Activities. Educational and Psychological Measurement, 30, 607-610. https://doi.org/10.1177/001316447003000308

Lambert, V. A., \& Lambert, C. E. (2001). Literature Review of Role Stress/Strain on Nurses: An International Perspective. Nursing \& Health Sciences, 3, 161-172. https://doi.org/10.1046/j.1442-2018.2001.00086.x

Lewis, D., \& Rayner, C. (2003). Bullying and Human Resource Management: A Wolf in Sheep's Clothing? In Bullying and Emotional Abuse in the Workplace: International Perspectives in Research and Practice (pp. 370-382). Taylor \& Francis. https://doi.org/10.1201/9780203164662.ch22

Lim, S. et al. (2008). Personal and Workgroup Incivility: Impact on Work and Health Outcomes. Journal of Applied Psychology, 93, 95. https://doi.org/10.1037/0021-9010.93.1.95

Lim, V. K., \& Chin, J. (2006). Cyber Incivility at the Workplace: What Has Supervisor's Sex Got to Do with It? PACIS 2006 Proceedings, Kuala Lumpur, 6 July 2006, 80.

Lueders, A. E. (2008). You'll Need More than a Voltage Converter: Plugging European Workplace Bullying Laws into the American Jurisprudental Outlet. Arizona Journal of International and Comparative Law, 25, 197.

Maurer, R. (2013). Workplace Bullying: Laws on the Horizon. Society for Human Resources Management.

McIntyre, D. (2005). "My Way or the Highway": Managerial Prerogative, the Labour Process and Workplace Health. Health Sociology Review, 14, 59-68. https://doi.org/10.5172/hesr.14.1.59

Milkman, R. (1997). Farewell to the Factory: Auto Workers in the Late Twentieth Century. University of California Press. https://doi.org/10.1525/9780520918344

Mobley, W. H. (1977). Intermediate Linkages in the Relationship between Job Satisfaction and Employee Turnover. Journal of Applied Psychology, 62, 237. https://doi.org/10.1037/0021-9010.62.2.237

Namie, G. (2003). Workplace Bullying: Escalated Incivility. Ivey Business Journal, 68, 1-6.

Nunnally, J. C., \& Bernstein, I. H. (1994). Psychometric Theory.

Park, Y. et al. (2018). Daily Cyber Incivility and Distress: The Moderating Roles of Resources at Work and Home. Journal of Management, 44, 2535-2557.

https://doi.org/10.1177/0149206315576796

Patel, R. et al. (2020). Report from the American Society for Microbiology COVID-19 International Summit, 23 March 2020: Value of Diagnostic Testing for SARS-CoV-2/ COVID-19. The American Society for Microbiology.

https://doi.org/10.1128/mBio.00722-20 
Pearson, C. M. et al. (2000). Assessing and Attacking Workplace Incivility. Organizational Dynamics, 29, 123-137. https://doi.org/10.1016/S0090-2616(00)00019-X

Penney, L. M., \& Spector, P. E. (2005). Job Stress, Incivility, and Counterproductive Work Behavior (CWB): The Moderating Role of Negative Affectivity. Journal of Organizational Behavior: The International Journal of Industrial, Occupational and Organizational Psychology and Behavior, 26, 777-796. https://doi.org/10.1002/job.336

Porath, C. L., \& Pearson, C. M. (2012). Emotional and Behavioral Responses to Workplace Incivility and the Impact of Hierarchical Status. Journal of Applied Social Psychology, 42, E326-E357. https://doi.org/10.1111/j.1559-1816.2012.01020.x

Quine, L. (1999). Workplace Bullying in NHS Community Trust: Staff Questionnaire Survey. BMJ, 318, 228-232. https://doi.org/10.1136/bmj.318.7178.228

Rahim, A., \& Cosby, D. M. (2016). A Model of Workplace Incivility, Job Burnout, Turnover Intentions, and Job Performance. Journal of Management Development, 35, 1255-1265. https://doi.org/10.1108/JMD-09-2015-0138

Ramlawati, R. et al. (2021). External Alternatives, Job Stress on Job Satisfaction and Employee Turnover Intention. Management Science Letters, 11, 511-518. https://doi.org/10.5267/j.msl.2020.9.016

Rizzo, J. R. et al. (1970). Role Conflict and Ambiguity in Complex Organizations. Administrative Science Quarterly, 15, 150-163. https://doi.org/10.2307/2391486

Sakurai, K. (2020). Changes in the Frequency of Coworker Incivility: Roles of Work Hours, Workplace Sex Ratio, Supervisor Leadership Style, and Incivility. Japanese Psychological Research, 63, 177-189. https://doi.org/10.1111/jpr.12305

Schilpzand, P. et al. (2016). Workplace Incivility: A Review of the Literature and Agenda for Future Research. Journal of Organizational Behavior, 37, S57-S88.

https://doi.org/10.1002/job.1976

Schyns, B., \& Schilling, J. (2013). How Bad Are the Effects of Bad Leaders? A Meta-Analysis of Destructive Leadership and Its Outcomes. The Leadership Quarterly, 24, 138-158. https://doi.org/10.1016/j.leaqua.2012.09.001

Seashore, S. E. et al. (1982). Observing and Measuring Organizational Change: A Guide to Field Practice. New York: Wiley.

Seigel, M. L. (2004). On Collegiality. Journal of Legal Education, 54, 406.

Sharma, L. J. K., \& Singh, S. K. (2013). A Study on the Democratic Style of Leadership. International Journal of Management, \& Information Technology, 3, 54-57. https://doi.org/10.24297/ijmit.v3i2.1367

Spector, P. E. (1986). Perceived Control by Employees: A Meta-Analysis of Studies Concerning Autonomy and Participation at Work. Human Relations, 39, 1005-1016. https://doi.org/10.1177/001872678603901104

Spector, P. E. (1997). Job Satisfaction: Application, Assessment, Causes, and Consequences. Sage. https://doi.org/10.4135/9781452231549

Taylor, F. W. (2004). Scientific Management. Routledge. https://doi.org/10.4324/9780203498569

Theodosiou, M., \& Katsikea, E. (2007). How Management Control and Job-Related Characteristics Influence the Performance of Export Sales Managers. Journal of Business Research, 60, 1261-1271. https://doi.org/10.1016/j.jbusres.2007.05.003

Thompson, C. A., \& Prottas, D. J. (2006). Relationships among Organizational Family Support, Job Autonomy, Perceived Control, and Employee Well-Being. Journal of Occupational Health Psychology, 11, 100. https://doi.org/10.1037/1076-8998.10.4.100

Thompson, M. et al. (2016). We All Seek Revenge: The Role of Honesty-Humility in 
Reactions to Incivility. Journal of Behavioral and Applied Management, 17, 1165.

Vega, G., \& Comer, D. R. (2005). Sticks and Stones May Break Your Bones, But Words Can Break Your Spirit: Bullying in the Workplace. Journal of Business Ethics, 58, 101-109. https://doi.org/10.1007/s10551-005-1422-7

Warrick, D. (1981). Leadership Styles and Their Consequences. Journal of Experiential Learning and Simulation, 3, 155-172.

Wright, T. A., \& Cropanzano, R. (1998). Emotional Exhaustion as a Predictor of Job Performance and Voluntary Turnover. Journal of Applied Psychology, 83, 486. https://doi.org/10.1037/0021-9010.83.3.486

Yamada, D. C. (2004). Crafting a Legislative Response to Workplace Bullying. Emp. Rts. \& Emp. Pol'y J, 8, 475. 